\title{
Localized Pulmonary Interstitial Emphysema Which Occurred After Non-invasive Mechanical Ventilatory Support
}

\author{
Non-invaziv Mekanik Ventilatör Desteği Sonrası Gelişen Lokalize Akciğer Interstisyel \\ Amfizem
}

\author{
(D) Esra Türe1, (1) Hakan Ildır2, (1) Abdullah Yazar1, (D) Fatih Akın1, (D) Sevgi Pekcan³ \\ ${ }^{1}$ Necmettin Erbakan University Meram Medical Faculty, Department of Pediatric Emergency, Konya, Turkey \\ ${ }^{2}$ Necmettin Erbakan University Meram Medical Faculty, Department of Pediatrics, Konya, Turkey \\ ${ }^{3}$ Necmettin Erbakan University Meram Medical Faculty, Department of Pediatric Pulmonology, Konya, Turkey
}

\section{Abstract}

Pulmonary interstitial emphysema is a rare condition characterized by collection of air in the pulmonary interstitial tissue outside normal air passages as a result of injury to the alveoli and small airways, and accumulation of air within the perivascular adventitia. In this article, a 5.5-month-old infant who developed pulmonary interstitial emphysema as a result of noninvasive mechanical ventilatory (bilevel positive airway pressure) support in a pediatric intensive care unit, is discussed.

Keywords: Pulmonary interstitial emphysema, pneumomediastinum, pneumothorax

\section{Öz}

Akciğer interstisyel amfizem, alveoller ve küçük hava yollarının yaralanması ve perivasküler adventisya içinde hava birikmesi sonucu akciğer interstisyel doku içinde normal hava geçişlerinin dışında hava toplanması ile karakterize nadir görülen bir hastalıktır. Bu yazıda, çocuk yoğun bakım ünitesinde noninvaziv mekanik ventilatör (bilevel pozitif havayolu basıncı) desteği ile akciğer interstisyel amfizem gelişen 5,5 aylık olgu tartışılmıştır.

Anahtar Kelimeler: Akciğer interstisyel amfizem, pnömomediastinum, pnömotoraks

\section{Introduction}

Pulmonary interstitial emphysema (PIE) is a rare condition characterized by collection of air in the pulmonary interstitial tissue outside normal air passages as a result of injury to the alveoli and small airways, and accumulation of air within the perivascular adventitia. This accumulated air may lead to hyperinflation of the lungs, volume loss in the contralateral lung, mediastinal shift, cystic air spaces, pneumomediastinum, pneumothorax and death. ${ }^{1,2}$ Although it is frequently seen in preterm infants receiving mechanical ventilatory support with respiratory distress syndrome, it may also occur in term infants and patients without any mechanical ventilator support. It presents in two forms: localized and diffuse. The treatment approaches vary from conservative methods to surgery depending on the severity of clinical presentation. ${ }^{2}$
In this article, we present a patient who developed PIE as a result of noninvasive mechanical ventilatory [bilevel positive airway pressure, (BIPAP)] support in a pediatric intensive care unit (PICU).

\section{Case Report}

A 5.5-month-old female patient was re-admitted to another center because of persistent fever on the second day of outpatient treatment that was ordered due to the diagnosis of bronchiolitis with the complaints of cough and stertorous respiration. Oseltamivir, methylprednisolone and inhaled ipratropium bromide treatments were ordered and she was hospitalized. On the second day of hospitalization, the patient was referred to our hospital because of possibility of need for intensive care due to increased respiratory rate and 
distress. It was learned from her past history that she was born to a 35-year-old mother through cesarean section as a term $2880 \mathrm{~g}$ infant, there was nothing specific during her prenatal follow-up, and she was followed up in the postnatal period due to neonatal jaundice. General condition of the patient was poor at admission, cardiac apical beat was measured as 170 /minute, respiratory rate as 100/minute, blood pressure as $81 / 62 \mathrm{mmHg}$ and oxygen saturation as $90 \%$. Physical examination revealed tachypnea, tachycardia, intercostal, subcostal and suprasternal retractions, and crepitant rales in basal parts of both lungs. No sign of bronchospasm was observed. Other system examination findings were normal. Posteroanterior chest X-ray showed an atelectatic area in the upper lobe of the right lung (Figure 1). Laboratory tests were as follows: hemoglobin: $10.5 \mathrm{~g} /$ $\mathrm{dL}$, white blood cells: $6400 / \mathrm{mm}^{3}$, absolute neutrophil count: 3900, platelet: $389.000 / \mathrm{mm}^{3}$, erythrocyte sedimentation rate: $14 \mathrm{~mm} / \mathrm{h}$ and c-reactive protein: $16.5 \mathrm{mg} / \mathrm{L}$. Blood gas analysis revealed the followings: $\mathrm{pH}: 7.38, \mathrm{PaCO}_{2}$ : 38.6 $\mathrm{mmHg}$ and $\mathrm{PaO}_{2}: 105 \mathrm{mmHg}$. Continuous positive airway pressure (CPAP) support (Vision, Respironics) with a pressure of $5 \mathrm{cmH}_{2} \mathrm{O}$ was provided via an oronasal mask in the emergency department for the patient for whom treatment with ampicillin, cefotaxim and oseltamivir was continued. Because tachypnea and respiratory distress persisted, she was referred to the PICU in the same day of hospitalization. For the patient who did not have carbon dioxide retention in control blood gas analysis inhaled salbutamol and magnesium, and parenteral methylprednisolon were added to the current treatment and BIPAP support (Vision, Respironics) was initiated with vented oronasal mask. Inspiratory positive airway pressure was set at $16 \mathrm{cmH}_{2} \mathrm{O}$ and expiratory positive airway pressure at $5 \mathrm{cmH}_{2} \mathrm{O}$. Dexmedetomidine was given

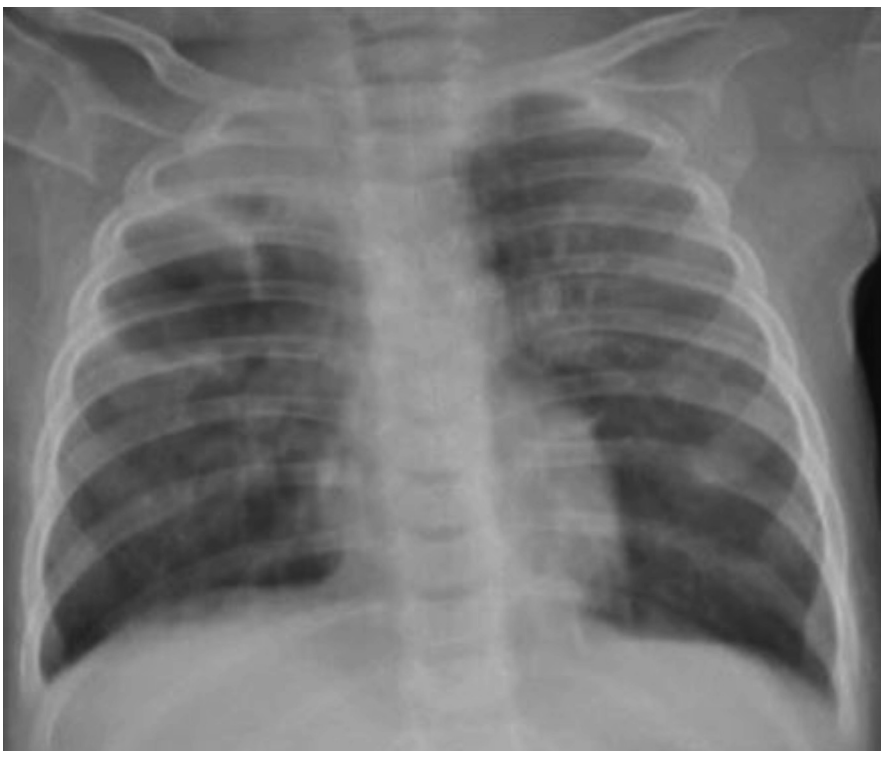

Figure 1. Posteroanterior chest X-ray at admission for sedation. Echocardiography was performed and cardiac functions were observed to be normal. Vancomycin was added to the treatment of the patient who still needed oxygen and had tachypnea by the second day of her hospitalization in the PICU. Control blood gas analysis was as follows: $\mathrm{pH}: 7.36, \mathrm{pCO}_{2}: 47.4 \mathrm{mmHg}_{1} \mathrm{PaO}_{2}: 108$ $\mathrm{mmHg}$ and $\mathrm{HCO}_{3}: 26,6 \mathrm{mEq} / \mathrm{L}$. Since there was a cystic appearance (Figure 2) in addition to areas of pneumothorax in posteroanterior chest X-ray of the patient who was followed up on BIPAP, thoracic computed tomography was taken, and atelectatic consolidations with air bronchograms in the upper lobe of the right lung, interstitial emphysema accompanied by bilateral pseudocystic appearances which were extending throughout the peribronchovascular sheath, pneumomediastinum and localized areas of pneumothorax were observed (Figure 3). Upon observation of PIE, pneumothorax and pneumomediastinum, the patient was weaned from the BIPAP in order to reduce barotraumas and oxygen therapy was initiated via a mask with a reservoir bag. Tachypnea and oxygen need decreased during her followup. On the $4^{\text {th }}$ day of hospitalization in the PICU, she was transferred to the pediatric chest diseases unit as she did not have tachypnea, respiratory distress or oxygen need; oxygen saturation remained normal; and there was no abnormality other than atelectasis (Figure 4) on posteroanterior chest X-ray. In the unit, oseltamivir was discontinued because it was administered for a sufficient dose and duration, and parenteral antibiotherapy was continued for one more week and then she was discharged with full recovery with a control visit scheduled. On the thoracic computed tomography taken 28 days after discharge, it was observed that the trachea and main bronchi were clear, bilateral pulmonary parenchymal areas and chest wall structures were natural and there was no pathological appearance detected (Figure 5).

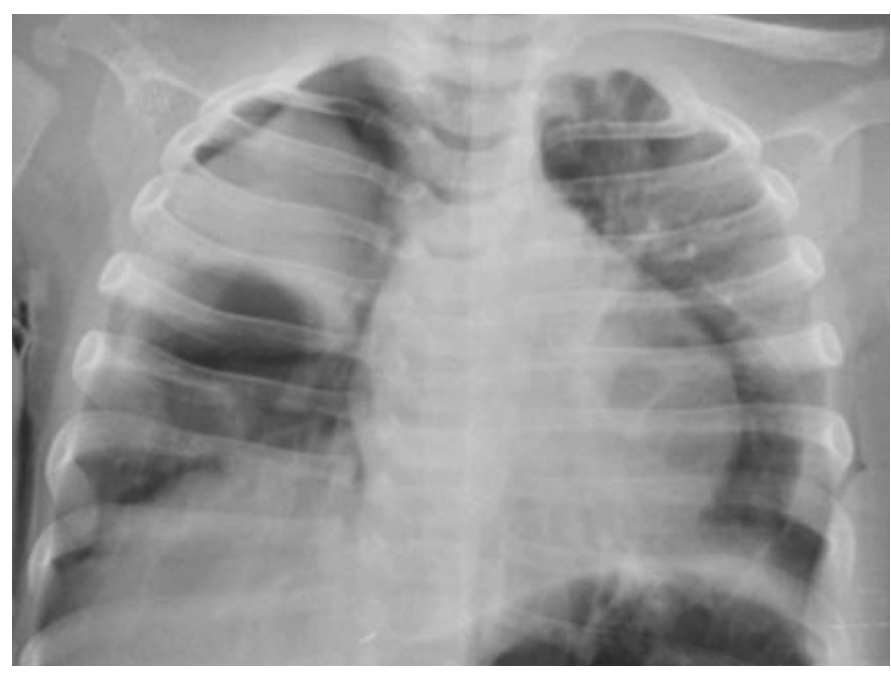

Figure 2. Posteroanterior chest X-ray after biphasic positive airway pressure support 

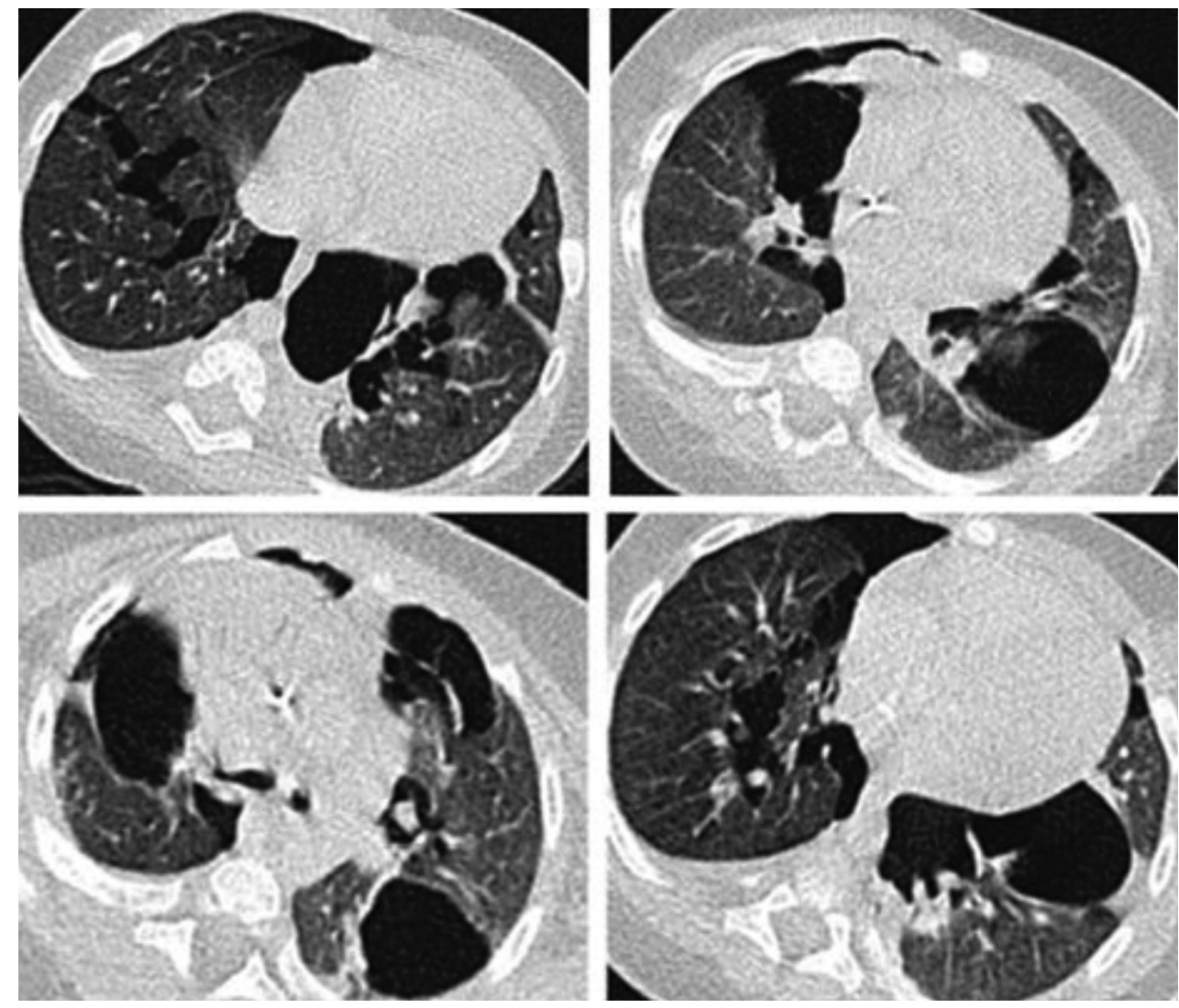

Figure 3. Computed tomography of thorax after biphasic positive airway pressure support

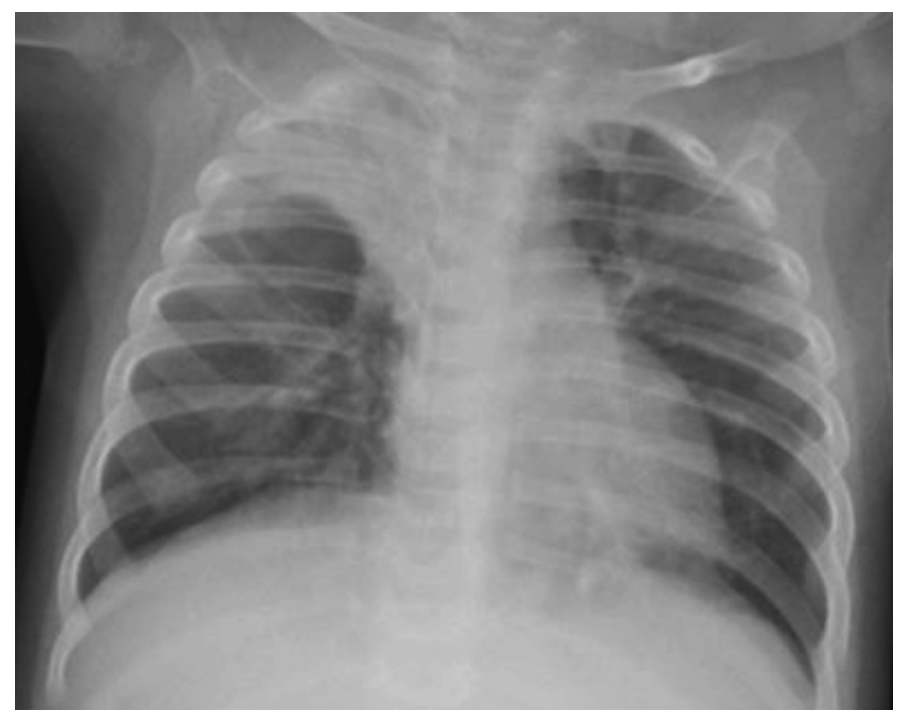

Figure 4. Posteroanterior chest X-ray taken two daysa after conlusion of biphasic positive airway pressure support

Informed consent was obtained from the patient's parents for publication of this case report.

\section{Discussion}

PIE, which generally occurs as a result of exposure to barotrauma in premature neonates with low lung compliance, leads to reduction of pulmonary perfusion, hypoxemia, carbon dioxide retention and respiratory distress as a result of pulmonary alveolar injury and leakage of air into interstitial tissues. ${ }^{1,3}$ Although PIE is more commonly encountered with use of conventional pressure-controlled mechanical ventilation, cases of PIE occurring after CPAP or spontaneously have also been reported in the literature., ${ }^{4,5}$

While conservative or surgical methods are preferred for treatment; the aim in conservative treatment is to provide sufficient oxygenation at the lowest mean airway pressure and by keeping carbon dioxide at an acceptable level. In these patients, continuing conventional invasive mechanical ventilation with high pressure leads to further enlargement of cysts and, especially in cases of localized PIE, to exposure of the healthy lung to compression. ${ }^{6}$ In our case, PIE that occurred while the patient was on BIPAP support, in order to eliminate barotraumas, BIPAP support was therefore terminated and oxygen support via mask was preferred, and clinical status of the patient was observed to recover dramatically. CPAP is a type of positive airway pressure which conveys room air to the patient at a desired pressure via a low-resistance hose and a mask, and allows keeping airways open continuously. BIPAP, however, is a type of positive airway pressure which ventilate at different pressures in inspiration and expiration throughout the respiratory cycle. ${ }^{7}$ Although 

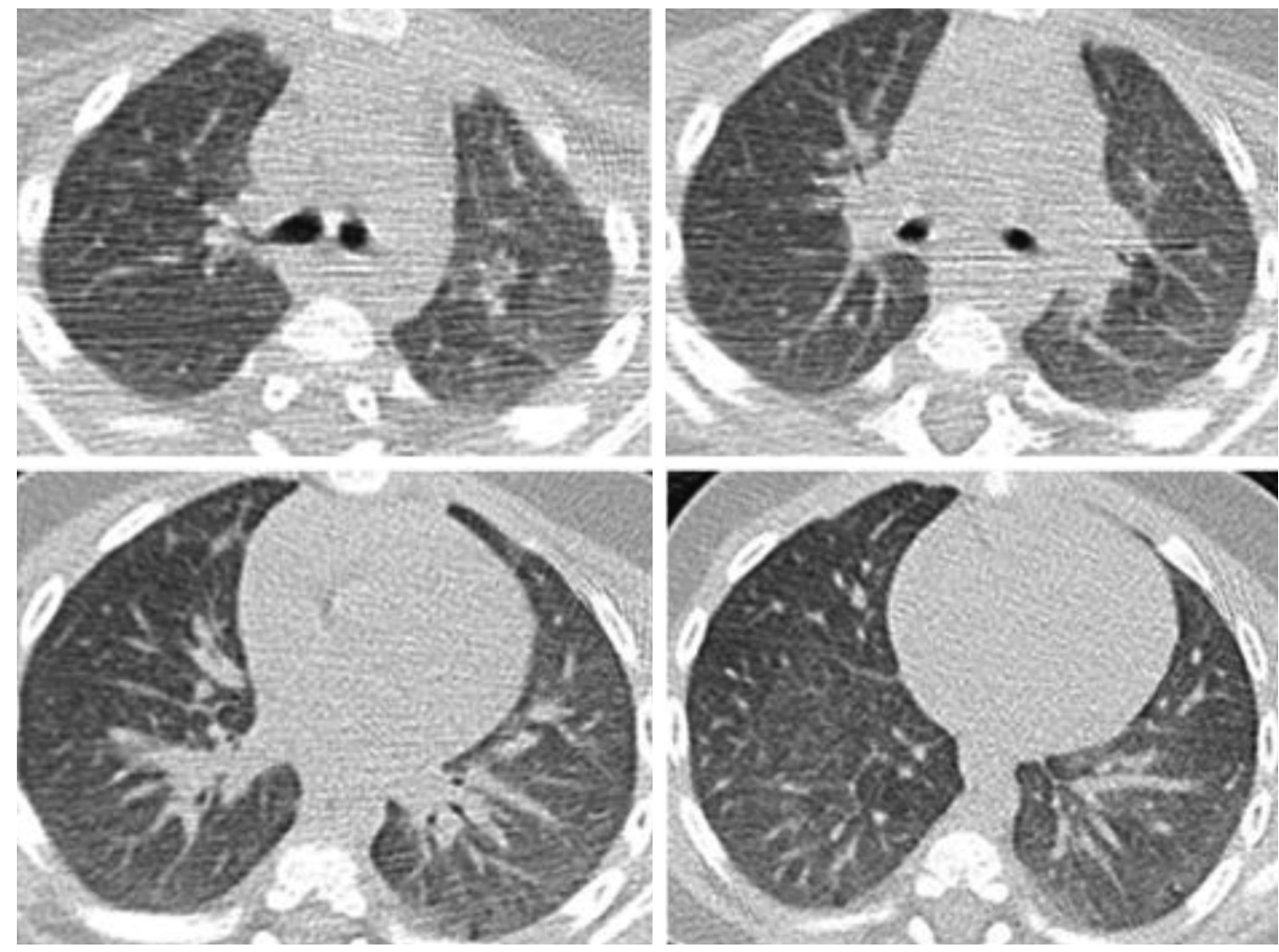

Figure 1. Normal computed tomography of thorax taken 28 days after discharge

some complications of noninvasive mechanical ventilator support have been identified, how it leads to development of PIE remains unknown. In a case of localized persistent PIE identified in a preterm infant being treated with CPAP by Bas et al. ${ }^{4}$, it was suggested that the current situation might be due to susceptibility of preterm lungs to alveolar rupture.

Differential diagnosis of PIE includes cystic adenomatoid malformation, lymphangiectasia, bronchogenic cysts, congenital lobar emphysema, cystic lymphangioma, diaphragmatic hernia and sequelae of previous infections ${ }^{8}$. Differentiation of PIE from other cystic lesions is important for treatment to be mostly conservative and for prevention of unnecessary surgical interventions.

In conclusion, our case of the 5.5-month-old infant who developed PIE as a result of noninvasive mechanical ventilator support shows that PIE may also occur in those not receiving conventional pressure-controlled mechanical ventilator support or premature neonates. In patients with respiratory problems, consideration of PIE in differential diagnosis would lead to not only prevention of unnecessary surgical interventions, but also to reduction of mortality and morbidity.

\section{Ethics}

Informed Consent: A consent form was completed by all participants.
Peer-review: Externally peer reviewed.

\section{Authorship Contributions}

Concept: E.T., H.I., A.Y., F.A., S.P., Design: E.T., H.I., A.Y., F.A., S.P., Data Collection or Processing: E.T., H.I., A.Y., F.A., S.P., Analysis or Interpretation: E.T., H.I., A.Y., F.A., S.P., Literature Search: E.T., H.I., A.Y., F.A., S.P., Writing: E.T., H.I., A.Y., F.A., S.P. Conflict of Interest: No conflict of interest was declared by the authors.

Financial Disclosure: The authors declared that this study received no financial support.

\section{References}

1. Cunningham K, Paes BA, Symington A. Pulmonary interstitial emphysema: a review. Neonatal Netw. 1992;11:7-16.

2. Sica M, Molinaro F, Angotti R, Mazzei O, Messina M. A case of diffuse persistent pulmonary emphysema: When is difficult the diagnosis? J Pediatr Surg Case Rep. 2016;12:11-5.

3. Elemen L, Baslo GG, Baş EK, Öz F, Erdoğan E. A Rare Cause of Dyspnea in a Newborn: Congenital Lobar Emphysema Accompanying Pulmonary Interstitial Emphysema. J Child. 2008;8:120-3.

4. Bas AY, Okumus N, Demirel N, Zenciroglu A. Persistent pulmonary interstitial emphysema in a preterm infant. Indian Pediatr. 2008;45:775-7. 
5. Berk DR, Varich LJ. Localized persistent pulmonary interstitia emphysema in a preterm infant in the absence of mechanical ventilation. Pediatr Radiol. 2005;35:1243-5.

6. Abu-Shaweesh J. Respiratory disorders in preterm and term infants. In: Martin R, Fanaroff A, Walsh M (ed). Fanaroff and Martin's Neonatal-Perinatal Medicine: Diseases of the Fetus and Infant(9th ed) St. Louis: Mosby, Inc, 2011:1164-6.
7. Pinto VL, Sharma S. Continuous Positive Airway Pressure (CPAP). 2018 Feb 12. StatPearls [Internet]. Treasure Island (FL): StatPearls Publishing; 2018 Jan-.Available from http://www.ncbi.nlm.nih.gov/ books/NBK482178/PubMed PMID: 29489216

8. Jones S, Kilgallon S, Schwartz AJ, Subramanyam R. Persistent Pulmonary Interstitial Emphysema. Anesthesiology. 2018. 